\title{
THE IMPACT OF FLOATING EXCHANGE RATE ON THE BEHAVIOR OF THE CONSUMERS FOR THE RED MEAT IN GHARBIA GOVERNORATE
}

\author{
GORABA, M.A. and M. A. ELSAWY \\ Agricultural Economics Research Institute, ARC, Doki, Giza.
}

(Manuscript received 1 April 2018)

\begin{abstract}

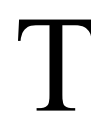
he central bank of Egypt issued the decree of floating the exchange rate of the Egyptian pound in September 2016 which lead to raise the prices of agricultural inputs generally and specially the inputs of animal production which import from outside and so raised the prices of red meat.

The most important results were:

1 -The rising in exchange rate by $10 \%$ leads to rises of the prices of the red meat, poultry and fish by $9.3 \%, 8.8 \%$ and 8.1 respectively. 2 -The rising in exchange rate by $10 \%$ leads to lowing in consumption of red meat by around $7.5 \%, 6 \%$ in rural and urban respectively for the first category of incomes and for the second and third categories of income were $2.9 \%, 2.5 \%$ in ruler and urban and $1.4 \%, 0.9 \%$ consequently. It clear that the low category of income was the lowest in consumption of the red meat after the floating exchange rate.

3 -An increasing in the red meat price by $10 \%$ leads to increased in consuming poultry by $8.1 \% \quad .7 .2$ in rural and urban for the first category of income and by $2.9 \%$. 3\% for the second and the third by $1.7 \%, 2.4 \%$ respectively . That means the categories of the low income were the highest in changing the pattern of consumption poultry instead of red meat and substitute it .

4-An increasing in red meat price by $10 \%$ leads to increasing in consuming the fish by $6.2 \%, 7.3 \%$ in rural and urban respectively for the first category of income and the second by $3.2 \%, 4.2 \%$ and the third by $1.5 \%, 2.2 \%$ in the rural and urban for the categories of income consequently .

Recommendations:-

1-Establishing studies about the impact of the exchange rate before appliance.

2-The intervention of the government as supplier of the principal commodities in low price and control the level market price. 3-Rationalize the consumers to use the alternative cheaper goods than the expensive and lowing the amount consumption .
\end{abstract}




\section{أثثر تحرير سعر الصرف على سلوك المستهلكين للحوم الحمر اء بمحافظة الغربية}

محمد غازى غزابه و محمد عبد الخالق الصاوى

$$
\text { معهز بحوث الإقتصاد الزراعي - مركز البحوث الزراعبة - دقى - جيزه }
$$

\section{مقدمة}

يقصد بسعر الصرف عدد الوحدات من العملة المحلية التى يتم دفعها للحصول علـى وحـدة

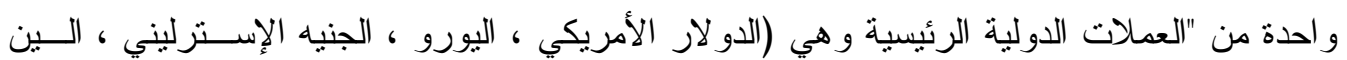

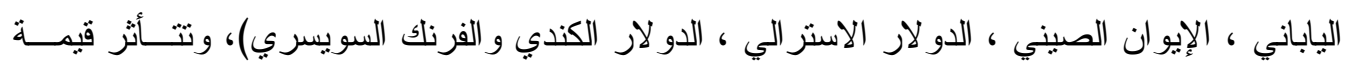

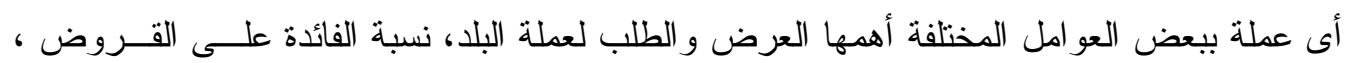
النضخم ، الفائض و العجز فى الميزان التجارى ، تقضيل السلع الأجنبية على السلع المحلية والإنتاج

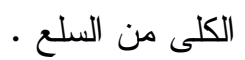

و تعتبر المنتجات الحيو انية من اللحوم الحمر اء من أهم مصـادر البروتينات اللازمـــة لغــذاء الإنسان ، يث تزود الجسم بالحديد و الزنك و العديد من الفيتامينات التي تدخل في تركيب الإنزيمات

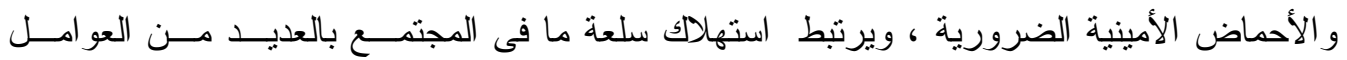

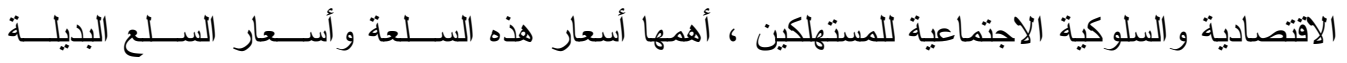

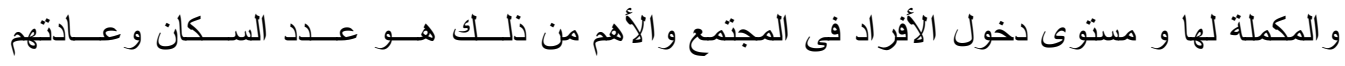

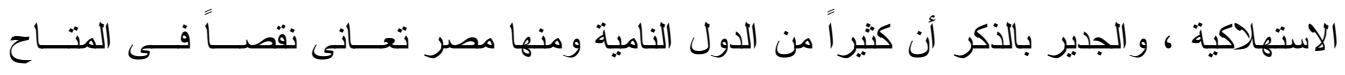

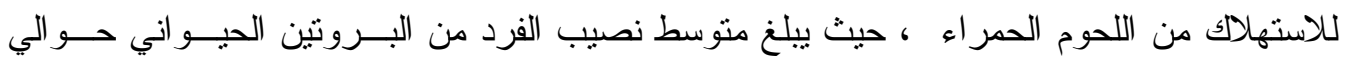

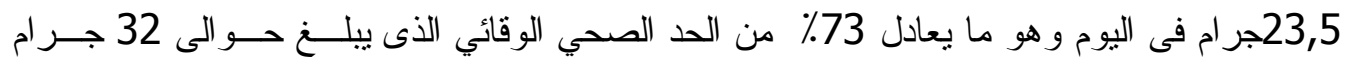

و تتميز أسواق المنتجات الحيو انية بالحساسية الكبيرة للتغيرات التى تحـدث فــى أســعار

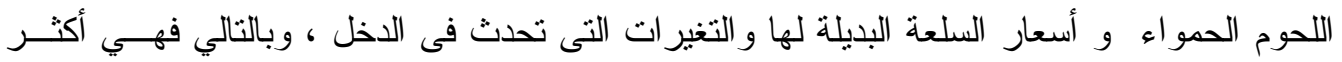

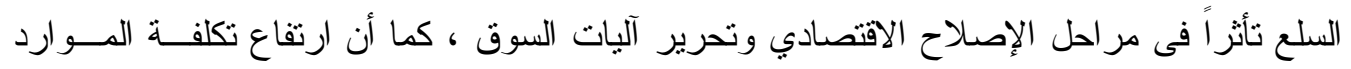

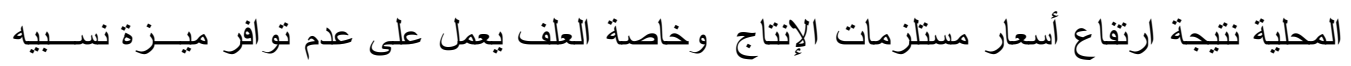

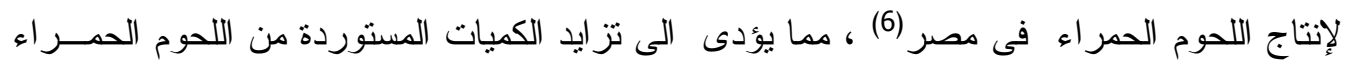

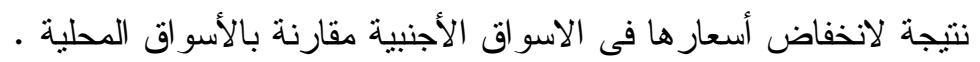

\section{مشكلة البحث}

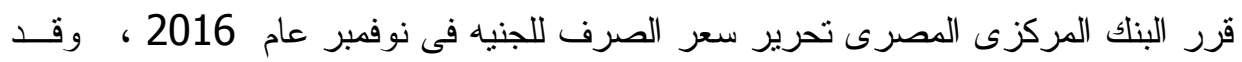

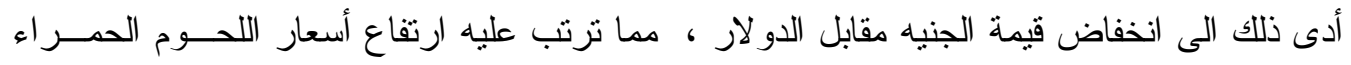

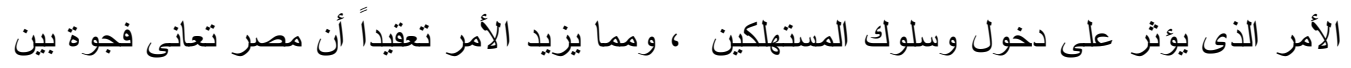

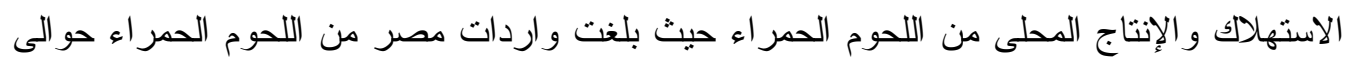


436,2 ألف طن من اللحوم الحمر اء تكلف الدولة حو الى 11,09 مليار جنيه عام 2015(9) مما أدى

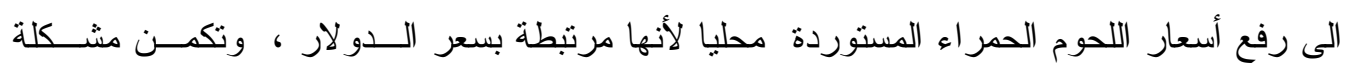

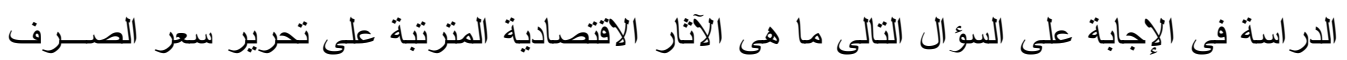

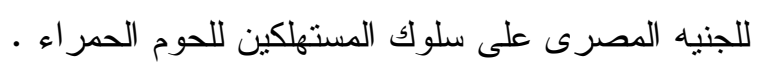

\section{هدف البحث}

يهذف هذا البحث الى دراسة أثز تحرير سعر الصرف للجنيـــه المصــرى علـى سـلوك

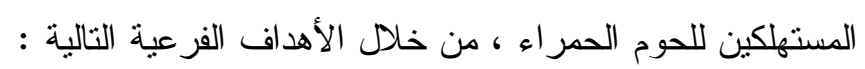

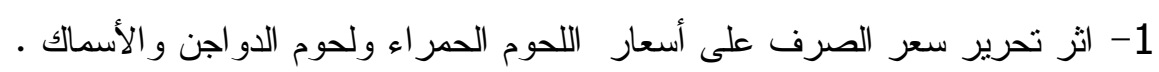

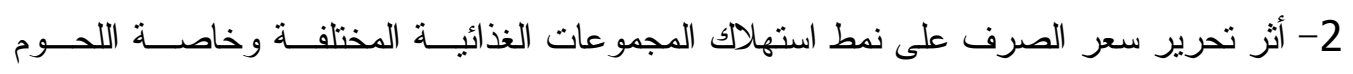
الحمر اء.

3- اثر تغير سعر الصرف على سلوك المستهلكين اللحوم الحمر اء ولحوم الدواجن و الأسماك .

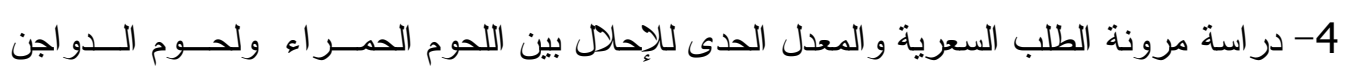
و الأسماك . مداك.

\section{الطريقة البحثية ومصادر البيانات}

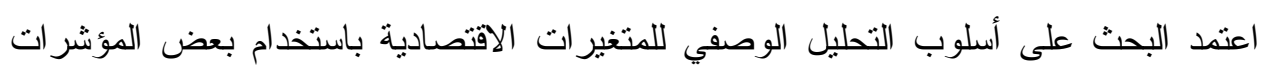

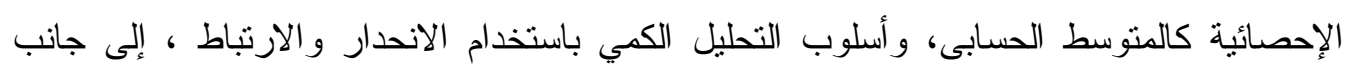

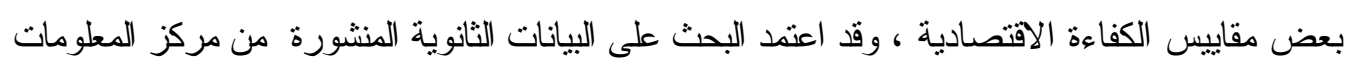

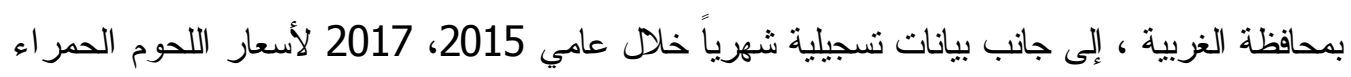

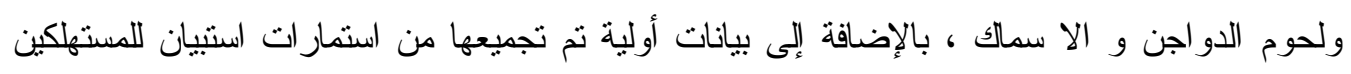
و المعدة لتحقيق أهداف البحث.

\section{أهمية البحث}

شهدت الفترة الأخيرة الكثير من التغير ات الاقتصادية نتيجة لتحرير سعر الصرف البف ، و التي

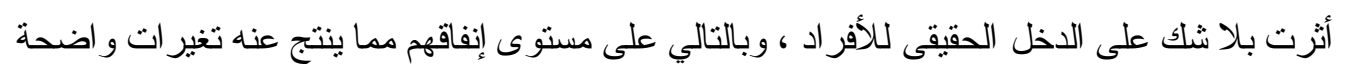

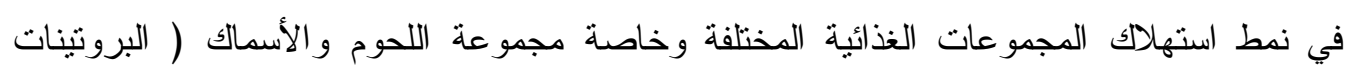

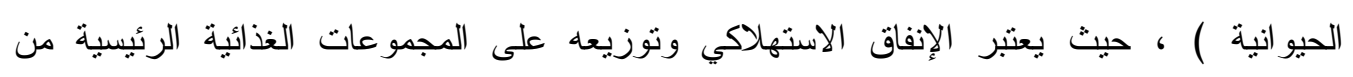

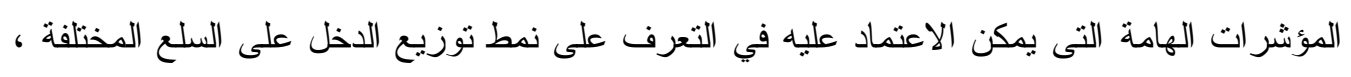

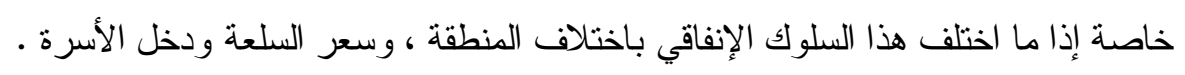

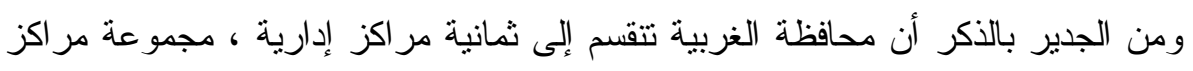
شمالية تضم مركز المحلة الكبرى ، سمنود ، قطور ، بسيون ومجموعة مر اكز جنوبية تضم مر اكز

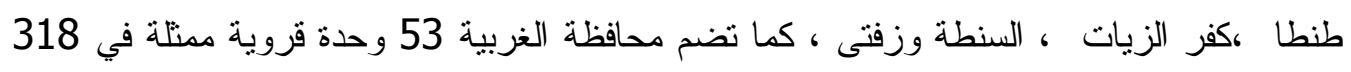

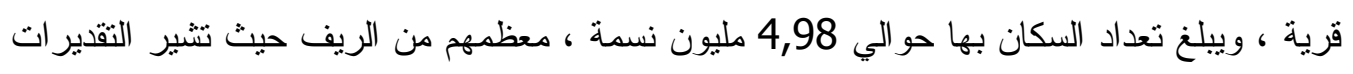

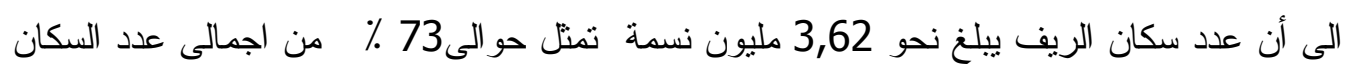
بالمحافظة (7) و الباقى من سكان الحضر . 


\section{عينة المستهلكين}

نم اختيار مركزين من مر اكز محافظة الغربية وفقاً للأهمية النسبية لعدد السكان ، وهما

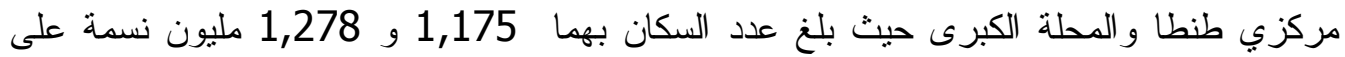
الترتيب يمثلان حوالي 23,8\% 25,9٪ من إجمالي عدد السكان بمحافظة الغربية و البالغ

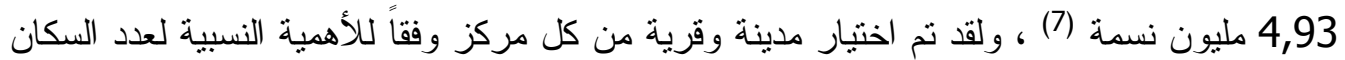
، حيث نم اختيار مدينة طنطا وقرية محلة مرحوم من مركز طنطا كما نم اختبار مدينة المحلة الكبرى وقرية بشبيش من مركز المحلة الكبرى ، ومن خلال السجلات الخاصة بأعداد السكان فقد نم اختيار عينة عشوائية من الأسر بالمدن والقرى المختارة ، ونم تحديد عدد أفراد العينة بحوالي 154 أسرة وذلك باستخدام القانون النالي (5): -

\section{$n=\frac{\mathbf{z}^{2} \sigma^{2} N}{\Delta^{2} N+z^{2} \sigma^{2}}$}

$$
\begin{aligned}
& \text { حيث أن: } \\
& \text { n : } \mathbf{n}
\end{aligned}
$$

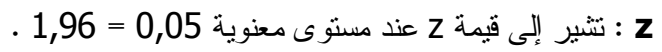

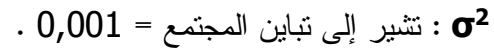

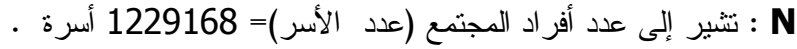

$$
\begin{aligned}
& \text { إ }
\end{aligned}
$$

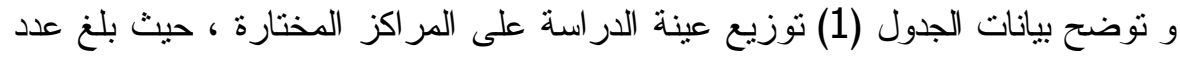

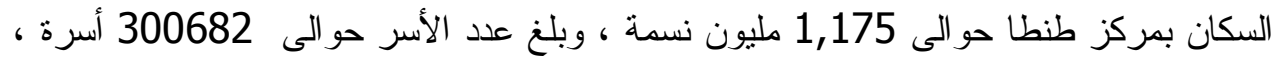
وباستخدام المتوسط الهندسى لنسبة أعداد الأسر و أعداد السكان فقد بلغ أعداد الأسر المختارة

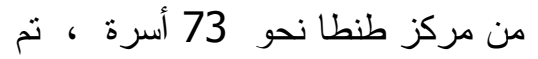

\begin{tabular}{|c|c|c|c|c|c|c|c|c|}
\hline \multicolumn{2}{|c|}{ عدد أفر اد العينة } & \multicolumn{2}{|c|}{ المنوسط الهندسى } & \multicolumn{2}{|c|}{ عدد الأسر } & \multicolumn{2}{|c|}{ عدد السكان } & \multirow{2}{*}{ 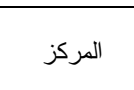 } \\
\hline ريف & حضر & ريف & حضر & ريف & حضر & ريف & حضر & \\
\hline 37 & 36 & 51 & 49 & \multirow{2}{*}{158694} & \multirow{2}{*}{141988} & \multirow{2}{*}{649062} & \multirow{2}{*}{525957} & \multirow{2}{*}{ طنطا } \\
\hline \multicolumn{2}{|c|}{73} & \multicolumn{2}{|c|}{47} & & & & & \\
\hline 45 & 36 & 55 & 45 & \multirow{2}{*}{182195} & \multirow{2}{*}{149497} & \multirow{2}{*}{719059} & \multirow{2}{*}{559619} & \multirow{2}{*}{ المحلة الكبرى } \\
\hline \multicolumn{2}{|c|}{81} & \multicolumn{2}{|c|}{53} & & & & & \\
\hline 82 & 72 & 53 & 47 & 340889 & 291485 & 1368121 & 1085576 & الجملة \\
\hline \multicolumn{2}{|c|}{154} & \multicolumn{2}{|c|}{100} & \multicolumn{2}{|c|}{632374} & \multicolumn{2}{|c|}{2453699} & الاجمالى \\
\hline
\end{tabular}

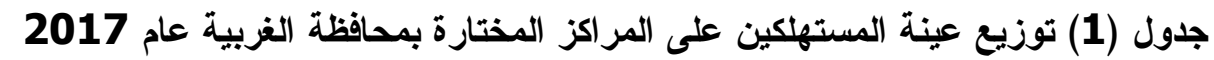

المصدر : محافظة الغربية ، مركز المعلومات ودعم اتخاذ القرار ، بيانات غير منشورة عام 2453617.

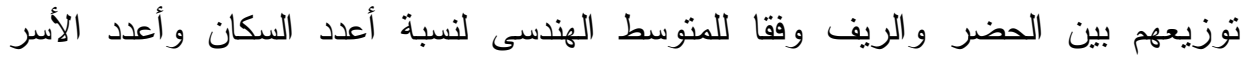

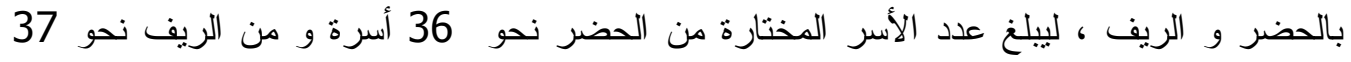

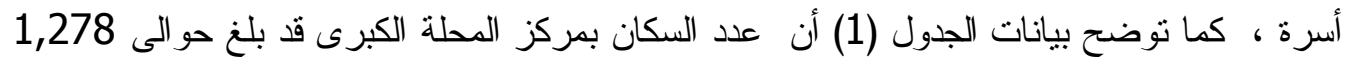
مليون نسمة ، وبلغ عدد الأسر نحو 331692 أسرة ، وباستخدام المتوسط الهندسى لنسبة أعداد الأسر و أعداد السكان فقد بلغ أعداد الأسر المختارة من مركز المحلة الكبرى نحو 81 أسرة، تم

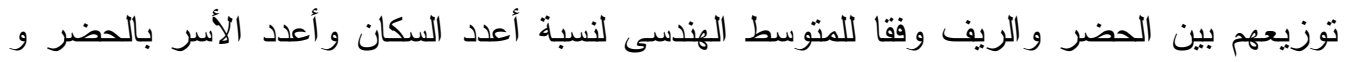
الريف ، ليبلغ عدد الأسر المختارة من الحضر نحو 36 أسرة و من الريف نحو 45 أسرة . 
وتوضح بيانات الجدول (2) توزيع عينة الدر اسة على المدن و القرى المختارة ، ومن البيانات

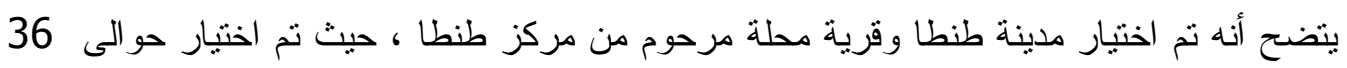

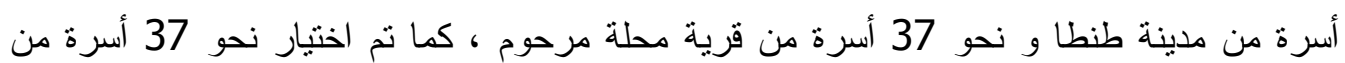

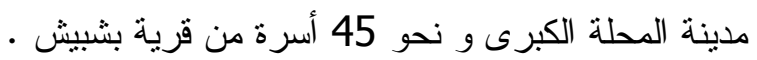

جدول (2) توزيع عينة الاراسة على القرى المختارة

\begin{tabular}{|c|c|c|}
\hline عدد أفر اد العينة & المدن و القرى & المركز \\
\hline 36 & biط & \multirow{3}{*}{ طنطا } \\
\hline 37 & محلة مرحوم & \\
\hline 73 & الجملة & \\
\hline 36 & المحلة الكبرى & \multirow{3}{*}{ المحلة الكبرى } \\
\hline 45 & بشبيش & \\
\hline 81 & الجملة & \\
\hline 154 & & الاجمالى \\
\hline
\end{tabular}

المصدر : توزيع عينة الدراسة عام 2017.

\section{التتائسج ومناقشتها}

اولا : أثر تحرير سعر الصرف على أسعار اللحوم الحمراء ومصادر البروتين الحيوانى البديلة لها

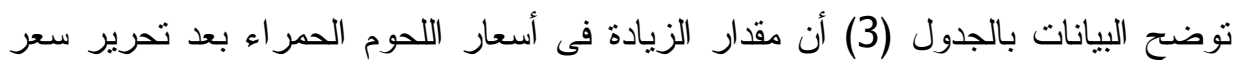

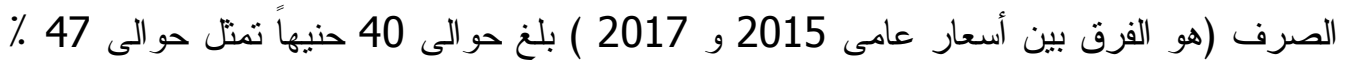
مما كانت عليه قبل تحرير سعر الصرف عام 2015 ، كما توضح البيانات بنفس الجدول ان مقدار

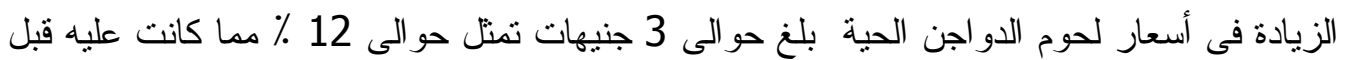
تحرير سعر الصرف ، وبلغ مقدار الزيادة فى أسعار الأسماك حو الى 5 حنيهات تمنتل حوالى 12

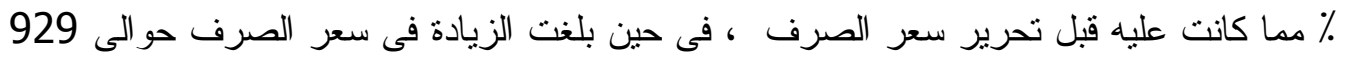

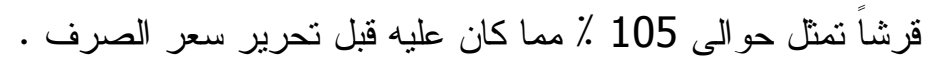

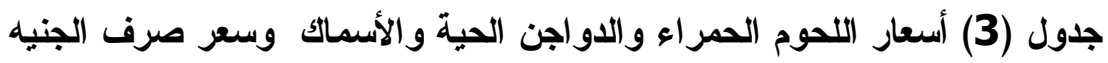

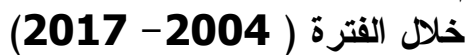

\begin{tabular}{|c|c|c|c|c|}
\hline سرش /دولار (2) & سنيه /كيلوجرام (1) & سكبل الدواجن الحية جنيه & سنيه /كيلوجرام الحوم (1) & 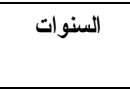 \\
\hline 568 & 7 & 6,0 & 25,0 & 2004 \\
\hline 578 & 9 & 7,0 & 26,0 & 2005 \\
\hline 579 & 10 & 8,0 & 29,0 & 2006 \\
\hline 581 & 11 & 8,0 & 32,0 & 2007 \\
\hline 583 & 11 & 11,0 & 36,0 & 2008 \\
\hline 591 & 12 & 12,0 & 40,0 & 2009 \\
\hline 595 & 14 & 12,0 & 53,0 & 2010 \\
\hline 602 & 17 & 14,0 & 58,0 & 2011 \\
\hline 604 & 20 & 20,0 & 62,0 & 2012 \\
\hline 617 & 20 & 22,0 & 67,0 & 2013 \\
\hline 760 & 22 & 24,0 & 75,0 & 2014 \\
\hline 886 & 25 & 25,0 & 85,0 & 2015 \\
\hline 1850 & 27 & 26,0 & 90,0 & 2016 \\
\hline 1815 & 30 & 28,0 & 125,0 & 2017 \\
\hline 802,9 & 16,7 & 15,9 & 57,4 & المتوسط \\
\hline 929 & 5 & 3 & 40 & مقار الزيادة \\
\hline 105 & 20 & 12 & 47 & نسبة الزيادة \% \\
\hline
\end{tabular}


ولتوضيح أثز ارتفاع سعر الصرف للجنيه على أسعار اللحوم الحمراء و أسعار لحوم الدو اجن و الأسماك ، تم دراسة العلاقة بين سعر الصرف للجنيه و أسعار اللحوم الحمر اءو و أسعار لحوم الدو اجن والأسماك حيث يعتبر سعر الصرف هو العامل المستقل والمؤثر على أسعار اللحوم الحمر اء والدواجن الحية و الأسماك كمتغير تابع ، ولقد تم التحليل باستخدام اسلوب الانحدار البسيط على الصورة اللوغارتمية المزدوجة ، و يتضح من بيانات الجدول رقم (4) أن ارتفاع سعر الصرف

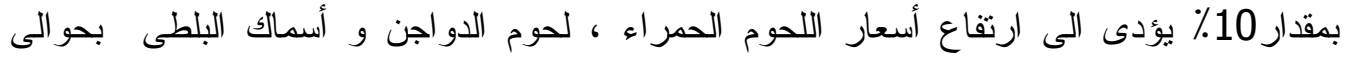

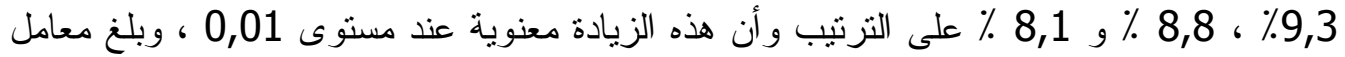
الارنباط البسيط 0,75، 0,67 و 0,73 على نفس الترتيب ، مما يعنى تأثر و ارتباط أسعار كل

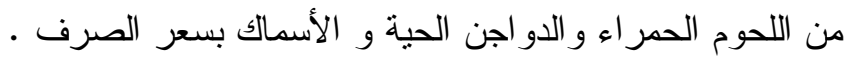

جدول ( 4) : معاملات الاتحدار والارتباط البسيط بين سعر الصرف لهرف للجنيه

أسعار اللحوم الحمر اءو والدواجن الحية و الأسماك

\begin{tabular}{|c|c|c|c|c|c|}
\hline $\mathrm{F}$ & $\mathrm{R}^{2}$ & $r$ & $\mathrm{~T}$ & $* \mathrm{~B}$ & 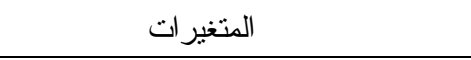 \\
\hline 15,9 & 0,57 & 0,75 & 3,9 & 0,93 & سعر اللحوم الحمر اء ( جنيه/كجم) \\
\hline 10,2 & 0,46 & 0,67 & 3,2 & 0,88 & سعر دجاج التسمين الحى ( جنيه /كجم ) \\
\hline 13,9 & 0,53 & 0,73 & 3,7 & 0,81 & سعر أسماك البلطى ( جنيه /كجم ) \\
\hline
\end{tabular}

* تم التحليل على الصورة اللوغارتمية المزدوجة .

المصدر : تحليل بيانات جدول (3) .

ثانيا : أثر تحرير سعر الصرف على سلوك مستهلكي اللحوم الحمر اءع بمحافظة الغربية

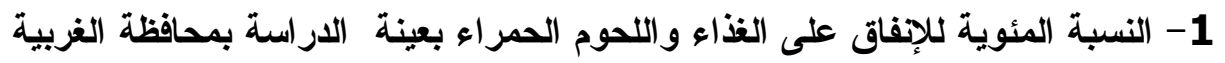
لدراسة أثز تحرير سعر الصرف على سلوك المستهلكين للحوم الحمراء كان من الضرورة

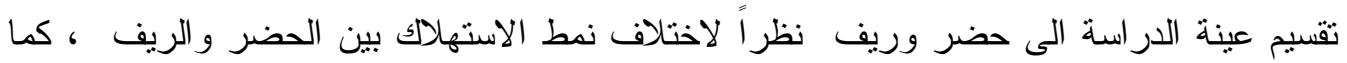

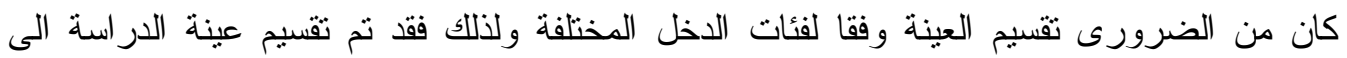
ثلاث فئات دخلية الأولى وهى فئات الدخل أقل من 2000 جنيه ، الثانية أكبر من 2000 جنيه

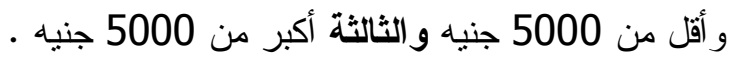

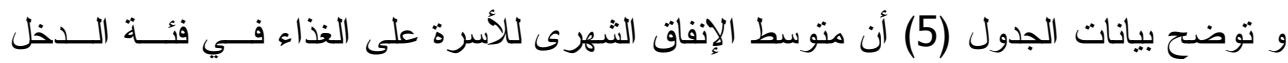

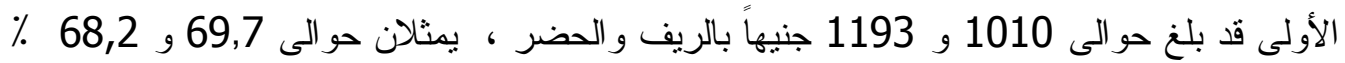

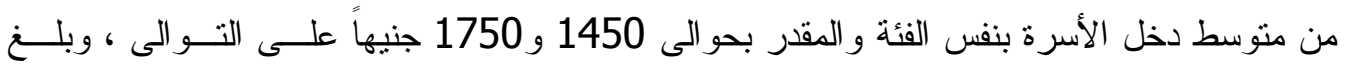

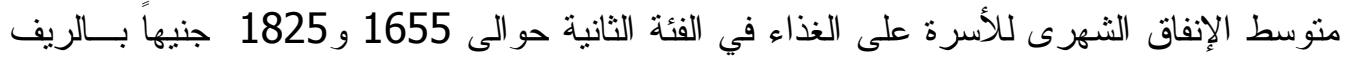

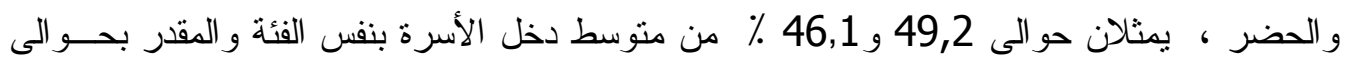

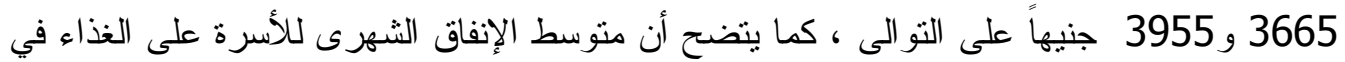

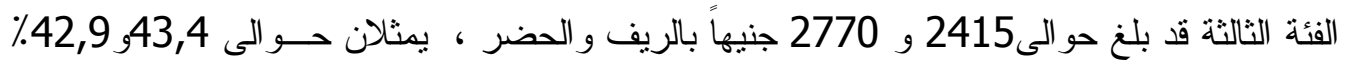
من دخل الأسرة بنفس الفئة و المقدر بحو الى 
كما يتضح من بيانات نفس الجدول أن متوسط الإنفاق الثهرى للأسرة على اللحوم الحمــراء

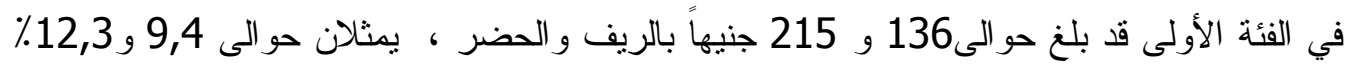

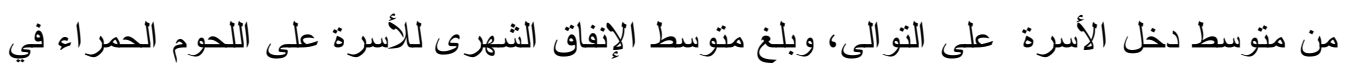

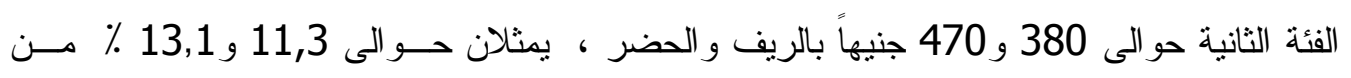

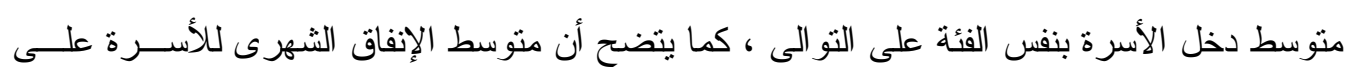

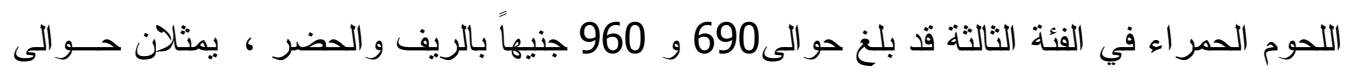
12,2 , و 14,2 من منوسط دخل الأسرة بنفس الفئة .

جدول (5 ) متوسط الإنفاق الشهزى على الغذاء بعينة الدراسة بمحافظة الغربية عام 2017

\begin{tabular}{|c|c|c|c|c|c|c|}
\hline \multicolumn{2}{|c|}{ الفئة الثالثة 5000 جنيها|شهر فأكثر } & \multicolumn{2}{|c|}{ 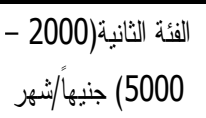 } & \multicolumn{2}{|c|}{2000 جنيها|شُشر } & \multirow[t]{2}{*}{ 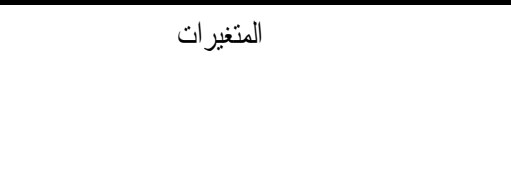 } \\
\hline ريف & حضر & ريف & حضر & ريف - ت ايف & حضر & \\
\hline 12 & 14 & 28 & 23 & 42 & 35 & عدد الأسر المختارة \\
\hline 7,8 & 9 & 18,3 & 14,9 & 27,3 & 22,7 & الأهمية النسبية لعدد الاسر بالعينة \% \\
\hline 5 & 5 & 5 & 5 & 6 & 5 & متو سط عدد أفر اد الأسرة \\
\hline 5565 & 6450 & 3365 & 3575 & 1450 & 1750 & متوسط الدخل الثهرى بالجنيه \\
\hline 2415 & 2770 & 1655 & 1825 & 1010 & 1193 & متوسط الإنفاق على الغذاء بالجنبه \\
\hline 43,4 & 42,9 & 49,2 & 46,1 & 69,7 & 68,2 & الأهمية النسبية للإنفاق على الغذاء من الدذل % \\
\hline 180 & 140 & 180 & 145 & 190 & 165 & متو سط الإنفاق على الحبوب و الخبز بالجنيه \\
\hline 325 & 350 & 290 & 295 & 150 & 170 & متوسط الإنفاق على الخضر و الفاكهة بالجنيه \\
\hline 260 & 270 & 220 & 230 & 145 & 165 & متوسط الإنفاق على منتجات الألبان و البيض بالجنبه \\
\hline 225 & 210 & 150 & 160 & 95 & 110 & متوسط الإنفاق على الزيوت والدهون بالجنيه \\
\hline 155 & 160 & 120 & 125 & 73 & 90 & متوسط الإنفاق على السكر والحلوي بالجنيه \\
\hline 690 & 960 & 380 & 470 & 136 & 215 & متوسط الإنفاق على اللحوم الحمر اء بالجنيه \\
\hline 310 & 360 & 165 & 210 & 115 & 145 & متوسط الإنفاق على لحوم الدو اجن بالجنيه \\
\hline 270 & 320 & 150 & 190 & 106 & 133 & متوسط الإنفاق على الأنسماك بالجنبه \\
\hline 12,2 & 14,9 & 11,3 & 13,1 & 9,4 & 12,3 & الأهمية النسبية للإنفاق على اللحوم الحمر اء من الدذل٪ \\
\hline 5,5 & 5,6 & 4,9 & 5,9 & 7,9 & 8,3 & الأهبية النسبية للإنفاق على لحوم الدواجن من الدذل \% \\
\hline 4,8 & 4,9 & 4,5 & 5,3 & 7,3 & 7,6 & الأهمية النسبية للإنفاق على الأسماك من الدذل \% \\
\hline
\end{tabular}

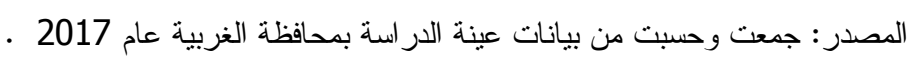

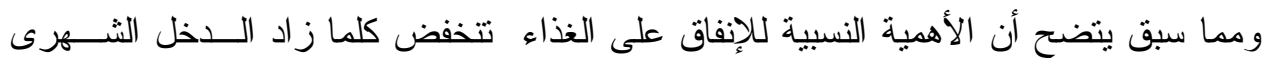

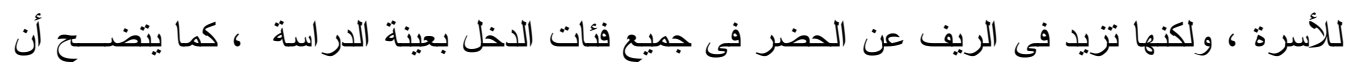

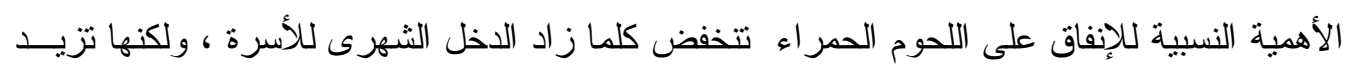

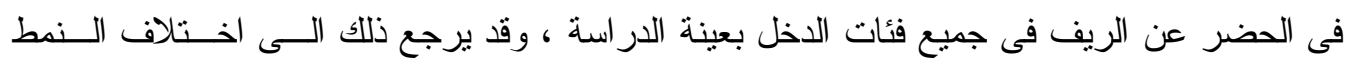

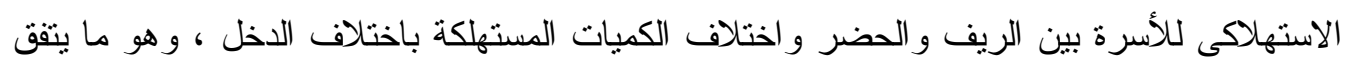

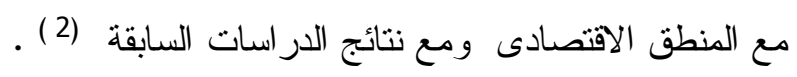




\section{2- اثز تحرير سعر الصرف على استهلاك اللحوم الحمراء بمحافظة الغربية}

توضح بيانات الجدول رقم (6) متوسط الاستهلاك السنوي لكلا من اللحوم الحمر اء ولحوم

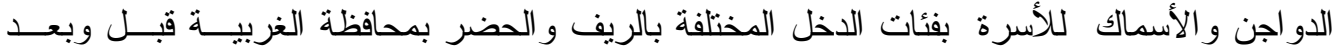
تحرير سعر الصرف ، حيث تمنل بيانات المستهلك عام 2015 قبل تحرير سعر الصــرف وتمثــل بيانات المستهلك في عام 2017 بعد تحرير سعر الصرف ، ومن البيانات يتضح أنــهـ قــد حـــث انخفاض في استهلالك اللحوم الحمر اء في جميع فئات الدخل في الريف و الحضر و إن اختلفــت نســبة الانخفاض بين الفئات وبعضها البعض كذلك اختلفت تللك النسبة بين الريف و الحضر بعينة الدراسة ، حيث تثبر البيانات الى أن متوسط استهلالك الأسرة من اللحوم الحمر اء بالريف و الحضر في الفئــة

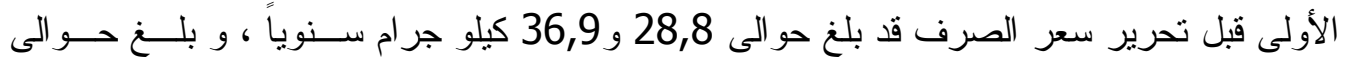

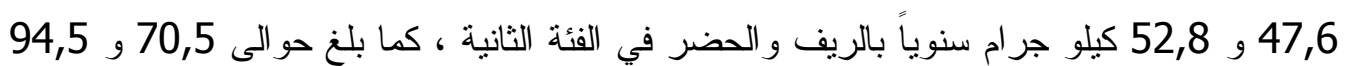

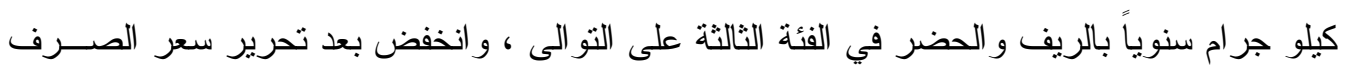

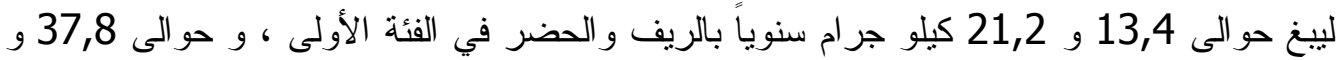

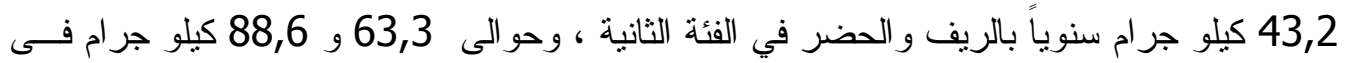
الريف و الحضر في الفئة الثالثة على النو الى. ومما سبق يتضـح أن ارتفاع اسعار اللحــوم الحمـــر اء نتيجة تغير سعر الصرف قد ادى الى انخفاض في استهلاك اللحوم الحمر اء في جميع فئات الــدخل ،

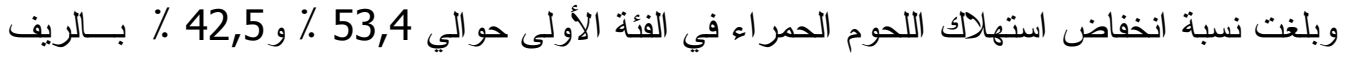

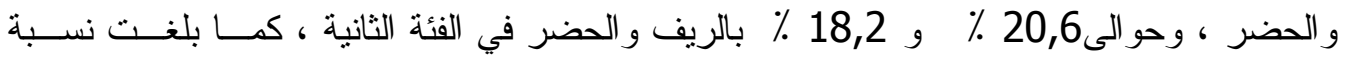

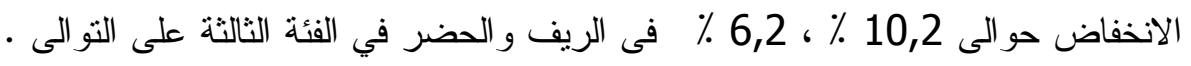
جدول رقم (6 ) متوسط كمية الاستهلاك السنوى للأسرة من اللحوم الحمراء ولحوم الدواجن

والأسماك قبل وبعد تحرير سعر الصرف بعينة الاراسة بمحافظة الغربية

\begin{tabular}{|c|c|c|c|c|c|c|c|}
\hline \multicolumn{2}{|c|}{ الأسماك } & \multicolumn{2}{|c|}{ ل لحوم الدواجن } & \multicolumn{2}{|c|}{ اللحوم الحمر اء } & \multirow{2}{*}{\multicolumn{2}{|c|}{ 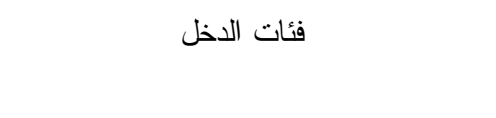 }} \\
\hline بعد & قبل & بعد & قبل & بعد & قبل & & \\
\hline 48,9 & 32,1 & 56,4 & 35,8 & 13,4 & 28,8 & ريف & \multirow[t]{2}{*}{ الأولى أقل من 2000 جنيها//شهر } \\
\hline 52,3 & 36,3 & 69,3 & 45,7 & 21,2 & 36,9 & حضر & \\
\hline 68,4 & 52,7 & 81,6 & 66,4 & 37,8 & 47,6 & ريف & \multirow{2}{*}{ 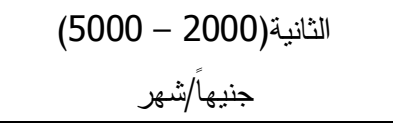 } \\
\hline 75,3 & 61,2 & 87,8 & 72,6 & 43,2 & 52,8 & حضر & \\
\hline 112,4 & 97,4 & 98,6 & 84,4 & 63,3 & 70,5 & ريف & \multirow[t]{2}{*}{ الثالثة أكبر من 5000جنيها//شهر } \\
\hline 132,8 & 119,6 & 125,4 & 111,7 & 88,6 & 94,5 & حضر & \\
\hline 28 & 23 & 24 & 21 & 120 & 70 & & متوسط السعر بالجنيه \\
\hline
\end{tabular}

المصدر : بيانات عينة الدراسة بمحافظة الغربية عام 2017 ـ

كما توضح البيانات بنفس الجدول السابق أن متوسط استهلالك الأسرة من لحوم الــدواجن

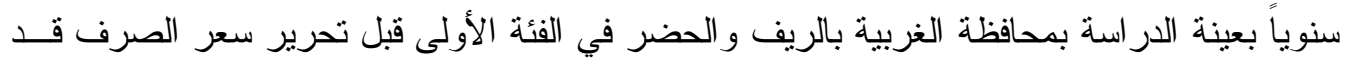

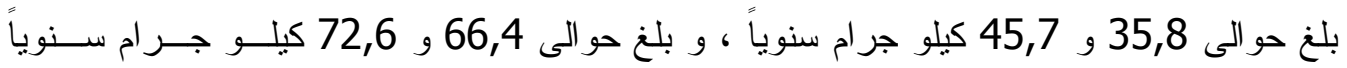

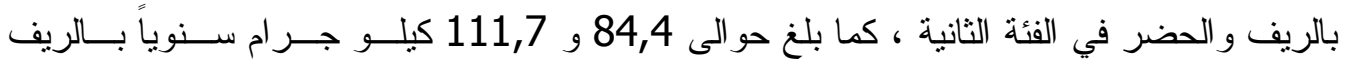




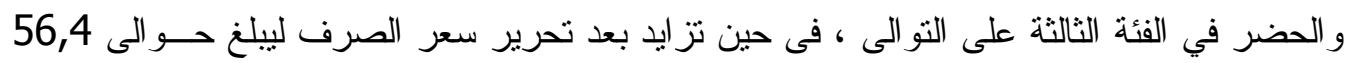

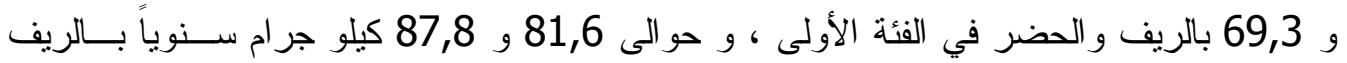

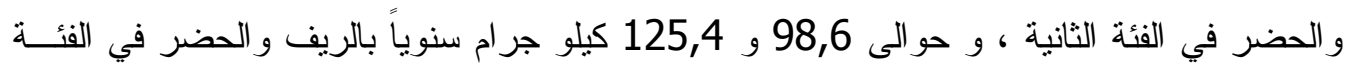

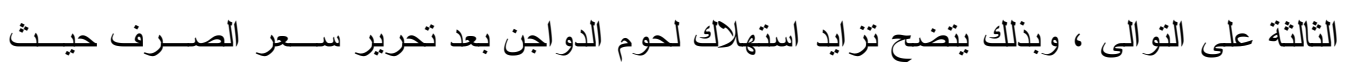

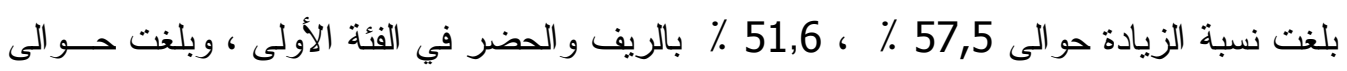

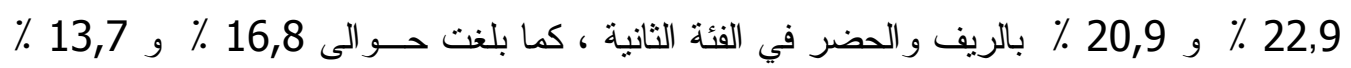

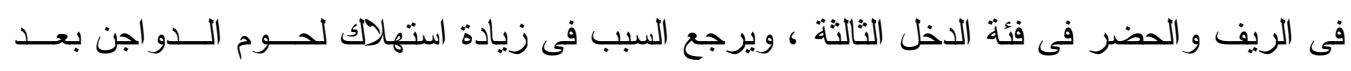

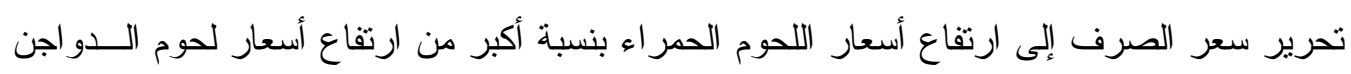

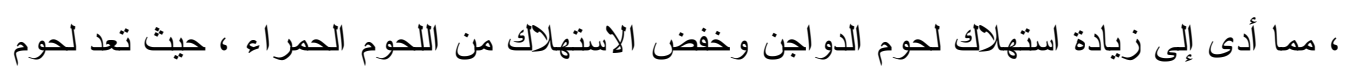

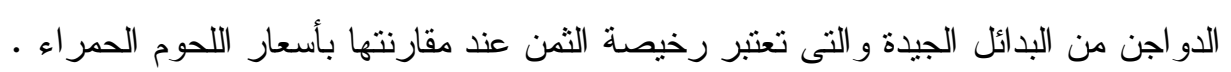

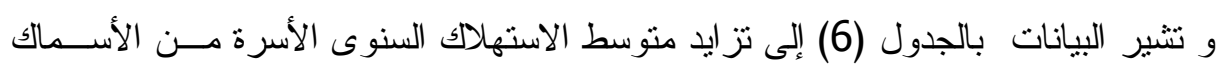

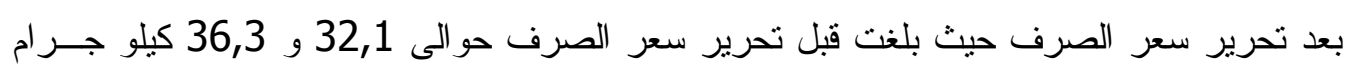

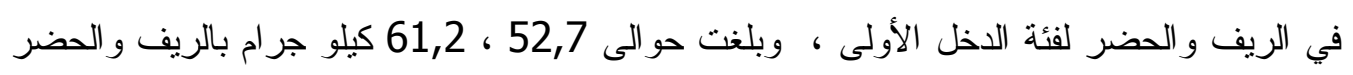
في الفئة الثانية ، و و حو الى 97,4 و 119,6 كيلو جرام سنوياً بالريف و الحضر في الفئة الثالثة على الثى

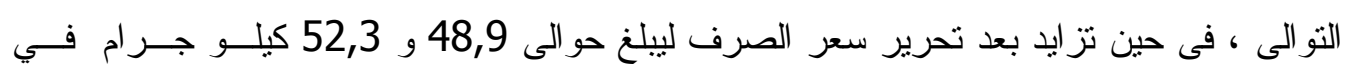

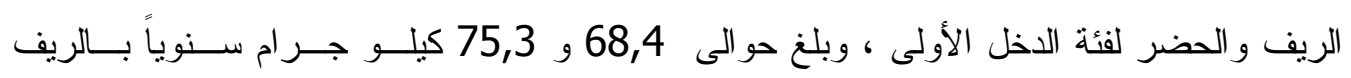

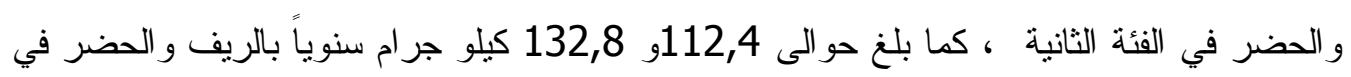

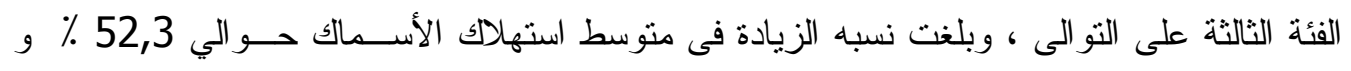

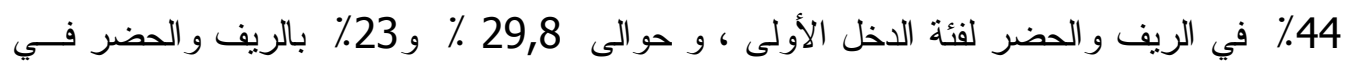

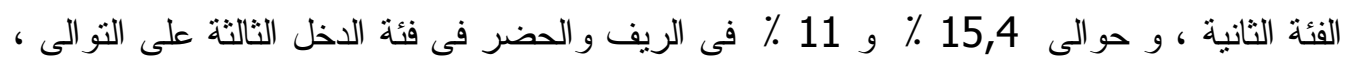

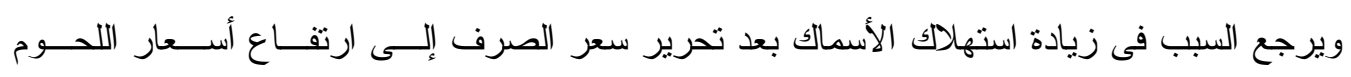

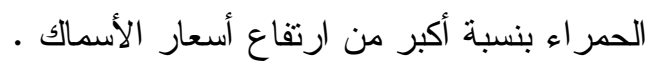

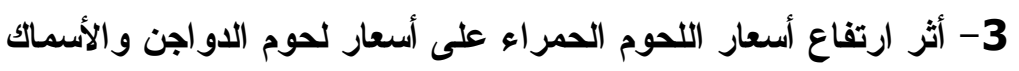

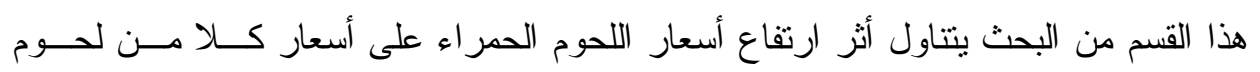

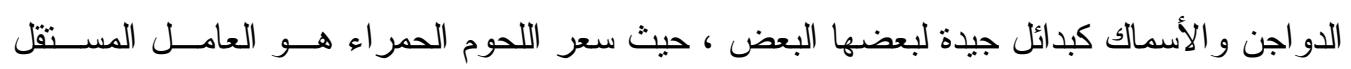

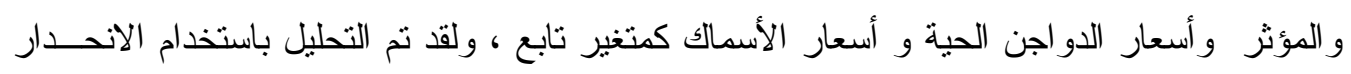

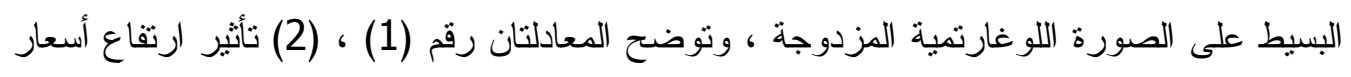

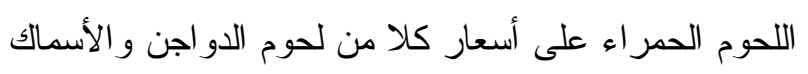

$\operatorname{Ln} y=-1.4+1.03 \operatorname{Ln} X_{2}$

$(13.6)^{* *}$

$R^{2}=0.93 \quad F=185.4$

$\operatorname{Ln} y=0.92+1.1 \operatorname{Ln} X_{3}$

$(18.9)^{* *}$

$R^{2}=0.96 \quad F=359.3$ 
ومن المعادلتان السابقتان يتضح أن زيادة أسعار اللحوم الحمر اء بنسبة 10٪ يؤدي إلى زيــادة

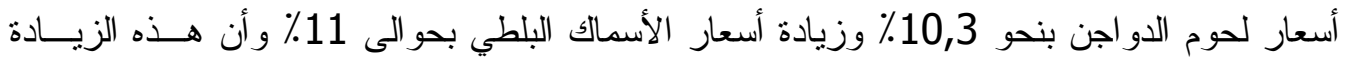

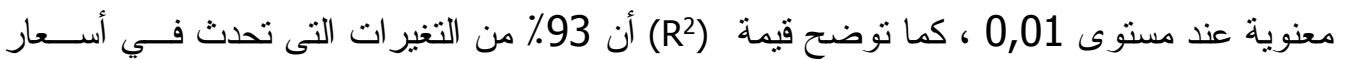

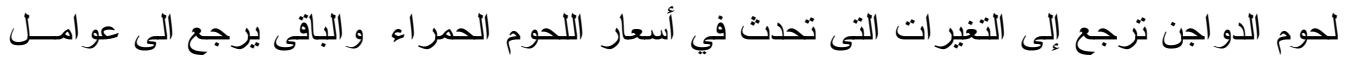
غير مقيسة ، وأن 96٪ من التغير ات التى تحدث في أسعار الأسماك ترجع إلى التغير ات التى تحدث

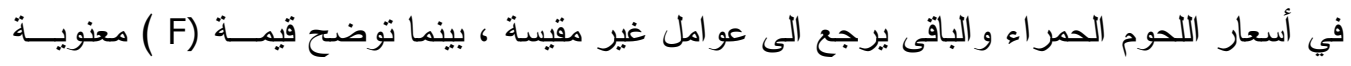

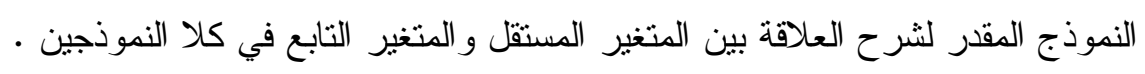
4 - أثر تحريز سعر الصرف على سلوك مستهلكي اللحوم الحمراء بمحافظة الغربية

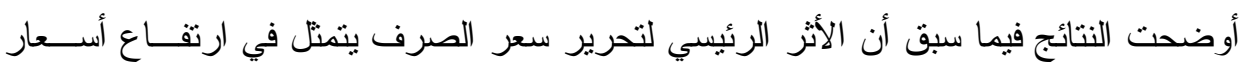

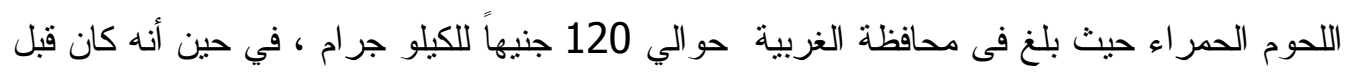

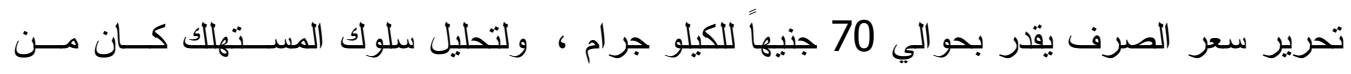

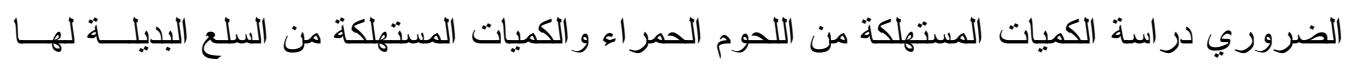

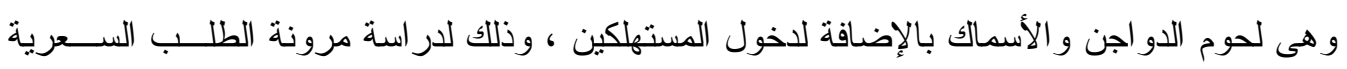

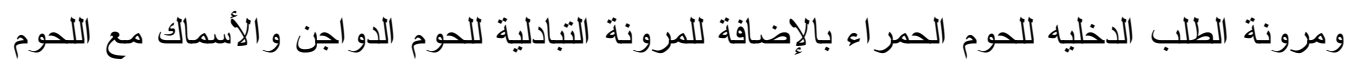

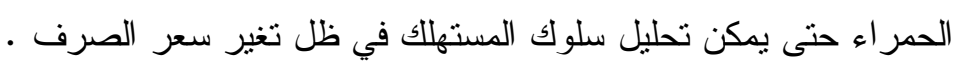
وتوضح بيانات الجدول رقم ( 7 ) أن مرونة الطلب السعرية لمستهلكي اللحوم الحمر اء بعينة

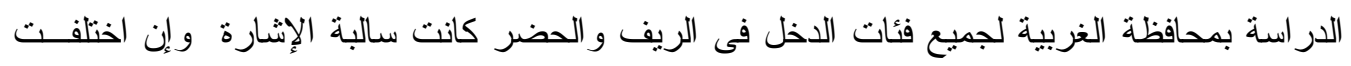

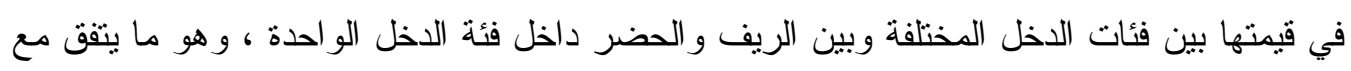

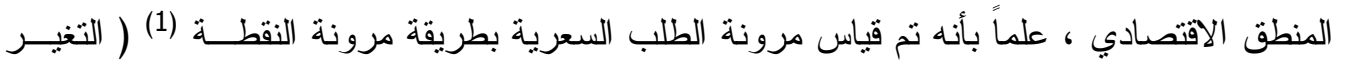

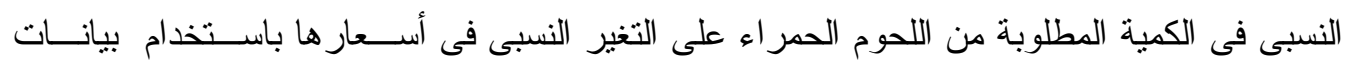

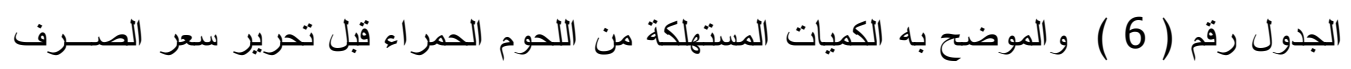

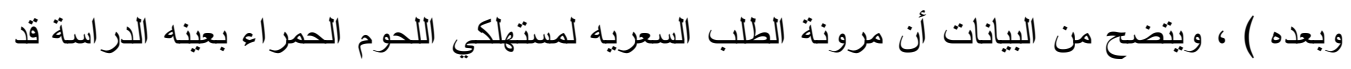

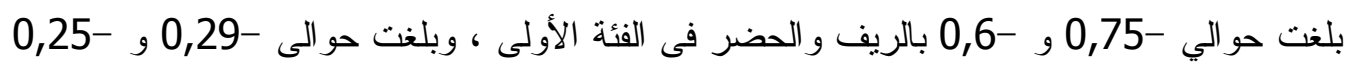

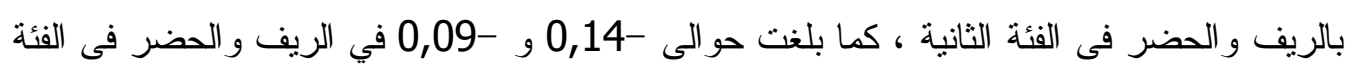

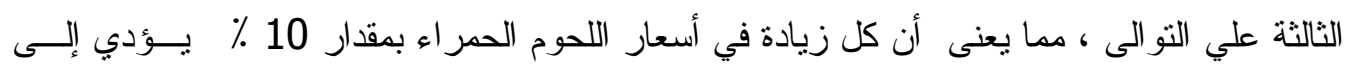

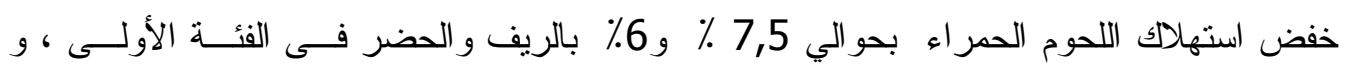

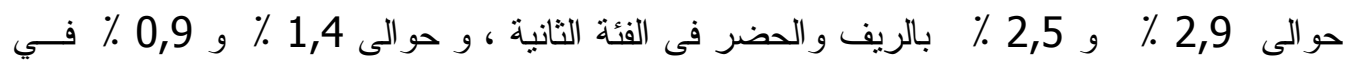

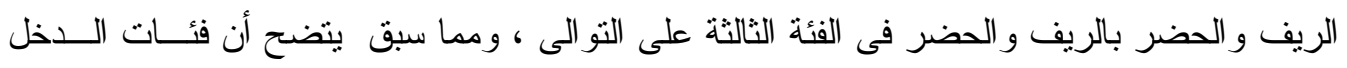

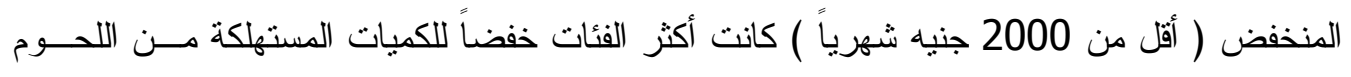

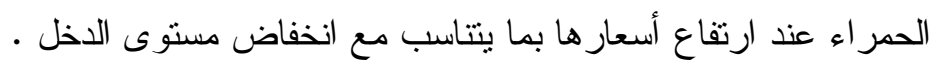


جدول (7) مرونة الطلب السعرية و الاخلية لمستهكى اللحوم الحمر اء بعينة الدراسة بمحافظة الغربية

\begin{tabular}{|c|c|c|c|c|c|c|c|}
\hline للإحلال مع الأسدى & للإحلال مع الحدى & للأسماك & اللمرونة اللبادلية & الطرونة & الطرونة & \multicolumn{2}{|c|}{ فئات الدخل } \\
\hline 1,09 & 1,34 & 0,73 & 0,81 & 0,17 & $0,75-$ & ريف & الأولى أقل من \\
\hline 1,02 & 1,69 & 0,62 & 0,72 & 0,32 & $0,6^{-}$ & حضر & 2000 جنيهاً / \\
\hline 1,60 & 1,45 & 0,42 & 0,30 & 1,36 & $0,29-$ & ريف & الثانية(2000 - \\
\hline 1,47 & 1,58 & 0,32 & 0,29 & 1,41 & $0,25-$ & حضر & 4000) جنيهاً / \\
\hline 2,21 & 2,08 & 0,22 & 0,24 & 1,59 & $0,14-$ & ريف & الثالثة أكبر من \\
\hline 2,24 & 2,32 & 0,15 & 0,17 & 1,72 & $0,09-$ & حضر & شهرجيهاً / \\
\hline
\end{tabular}

المصدر : بيانات عينة الدراسة بمحافظة الغربية عام 2017 ـ.

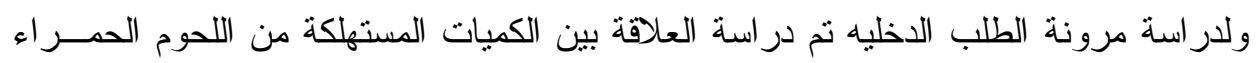
كمتغير تابع ودخول الأفر اد في الفئة الدخلية الواحدة بالريف والحضر كمتغير مستقل ، علما بأنه نم

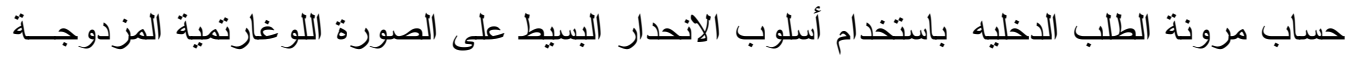

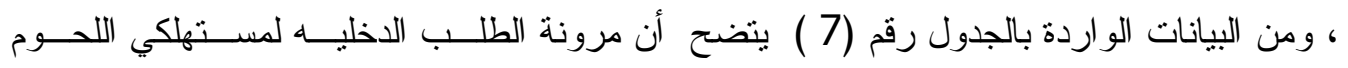

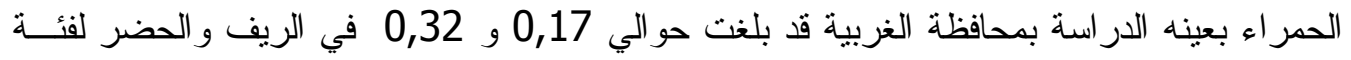

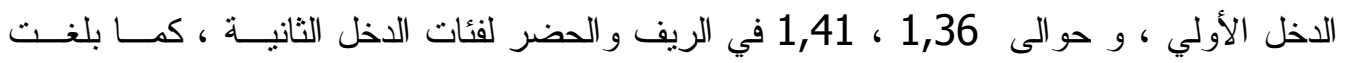

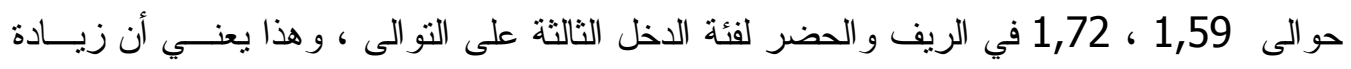

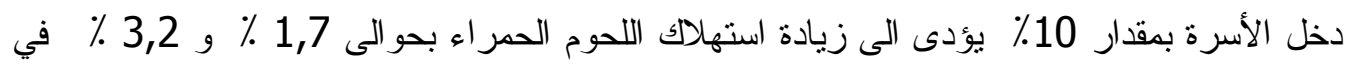

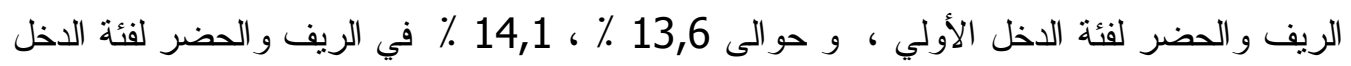

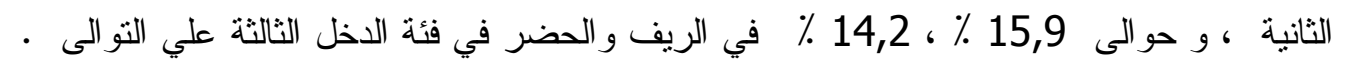

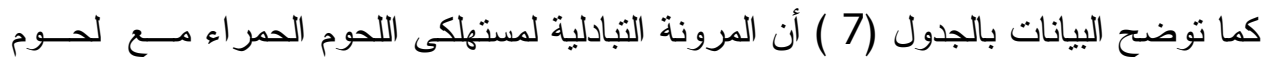
الدواجن ( مقدار التغير النسبي في الكميات المستهلكة من لحوم الدواجن على التغير النسبي لأســعار

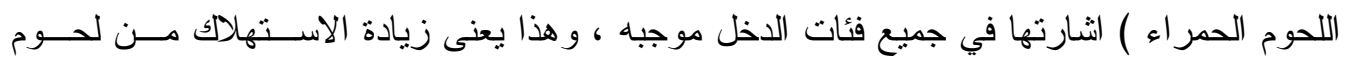

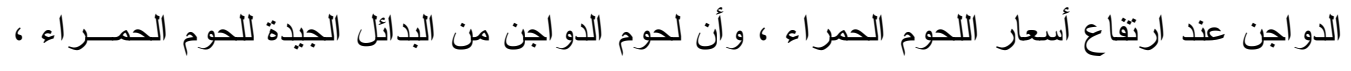

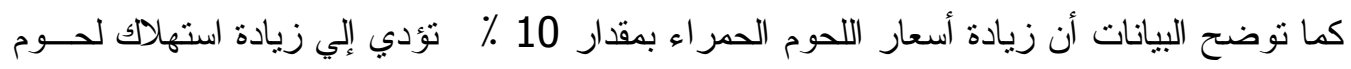

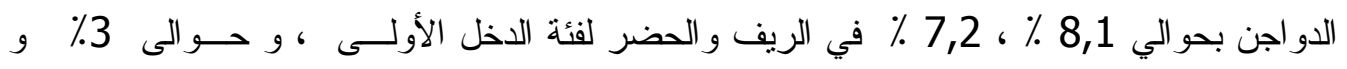

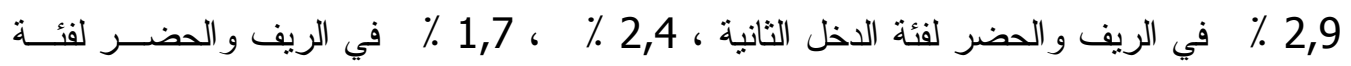

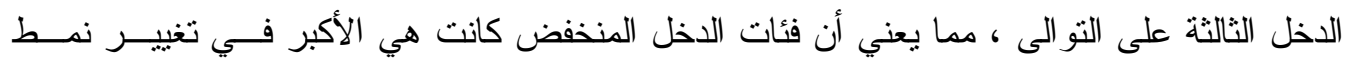

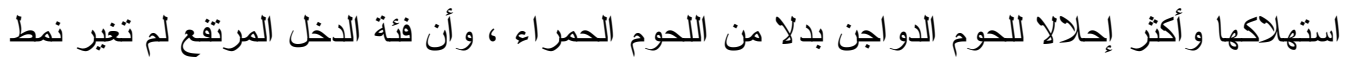

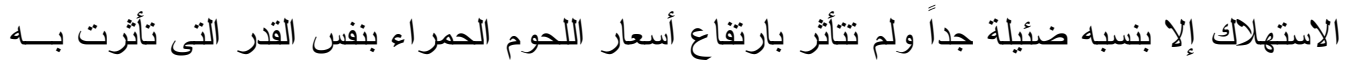


كما توضح المرونة التبادلية لمستهلكي اللحوم الحمر اء مع الأسماك ( مقدار التغير النسـبـي

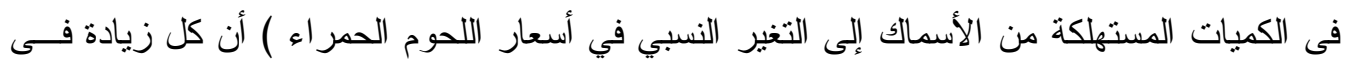

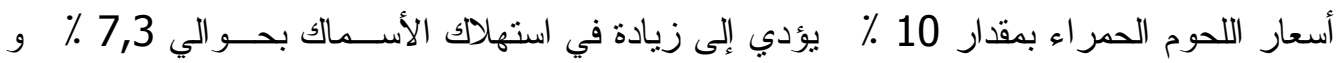

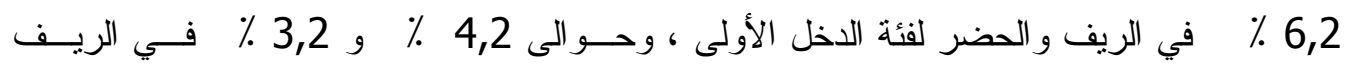

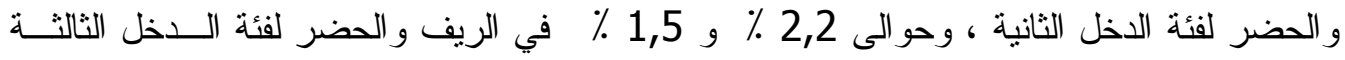
على التو الى ، و هذا يتفق مع المنطق الاقتصادى .

ثالثا : المعدل الحدي للإحلال بين اللحوم الحمراء و السلع البديلة لها ( الدواجن والأسماك ) يعرف المعدل الحدى للإحلال على أنه عدد الوحدات من سلعة ما (لحوم الدواجن أولى أو الأسماك)

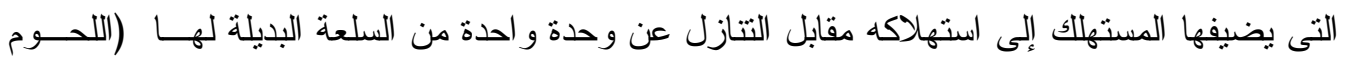

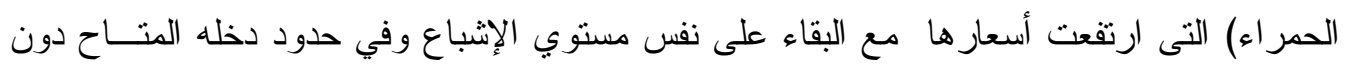
تغير

ومن الجدير بالذكر أن النظرية الاقتصادية تؤكد على أن المعدل الحدي للإحــلال يســاوي النســبة

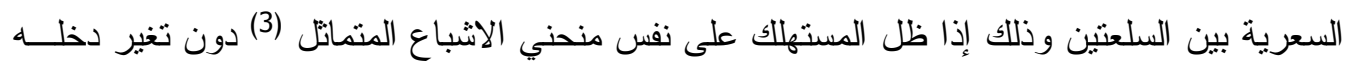

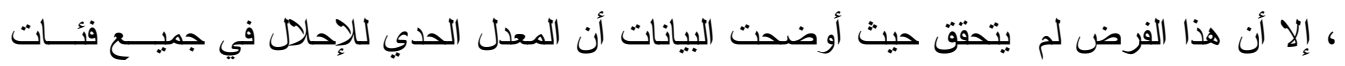
الدخل في الريف و الحضر كان أقل من النسبة السعرية و التى بلغت قيمتها 5 ( متوسط سعر اللحــوم الحمر اء و المقدر بنحو 120 جنيهاً مقسوما على متوسط سعر الدواجل الن و والمقدر بنحو 24 جنيهاً بعينة

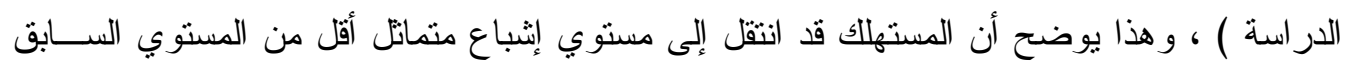

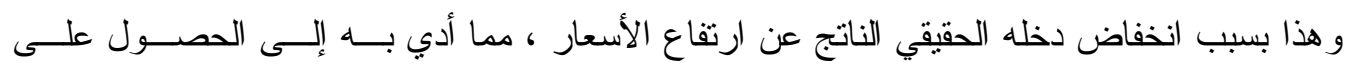

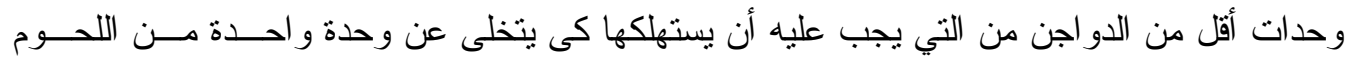

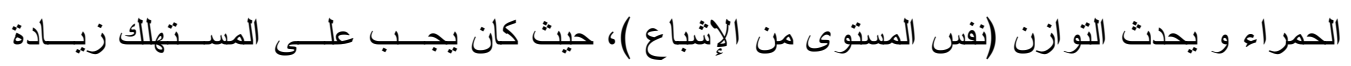

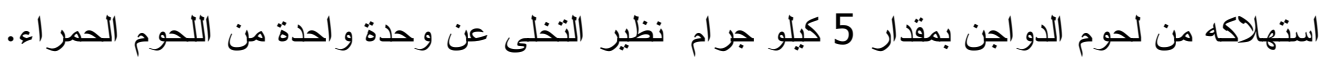

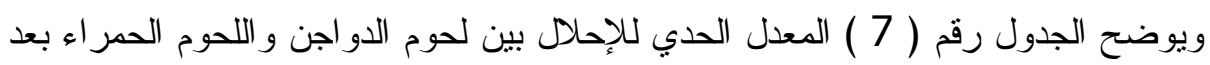

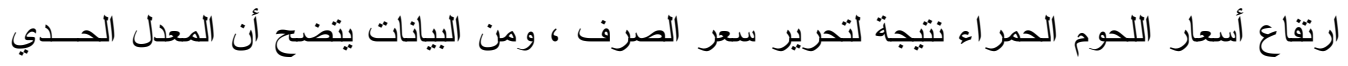

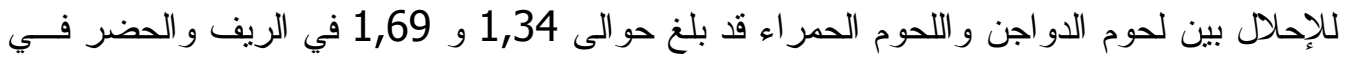

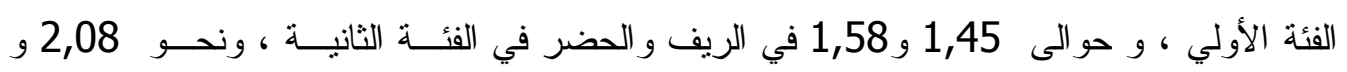

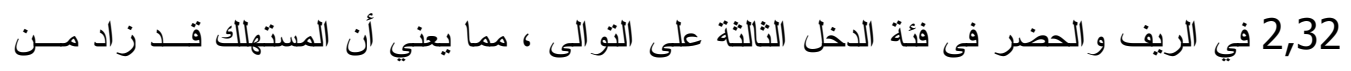

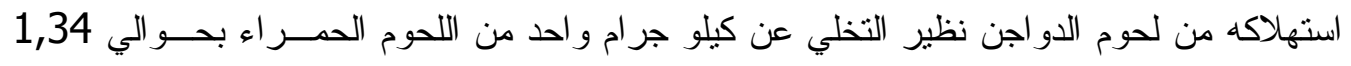

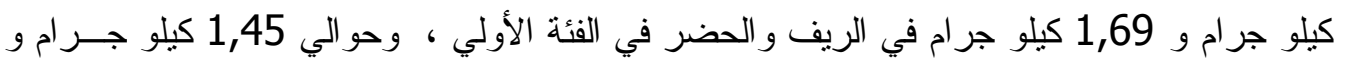

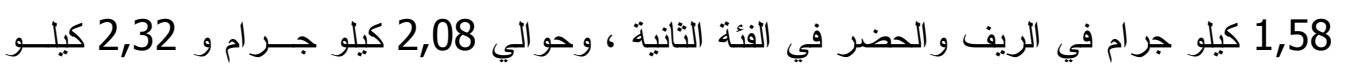

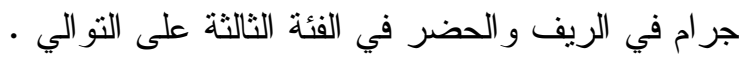

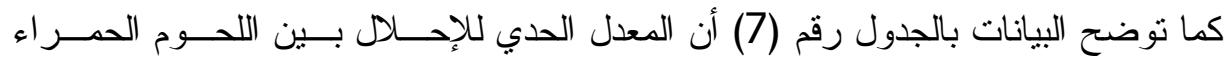

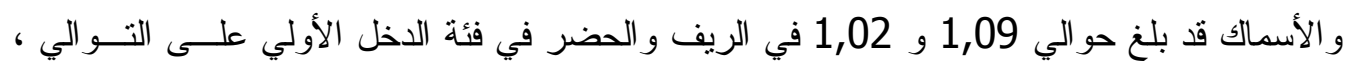

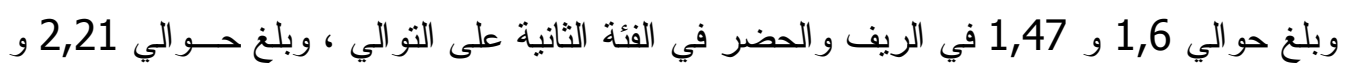

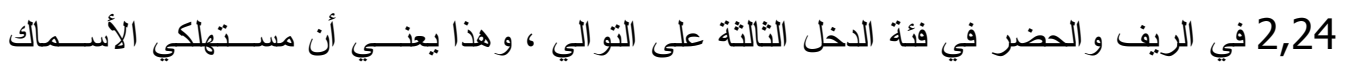

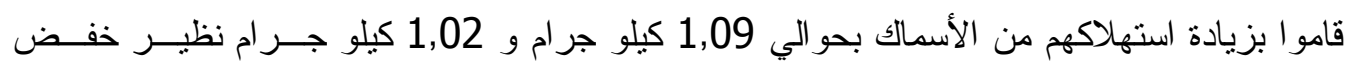




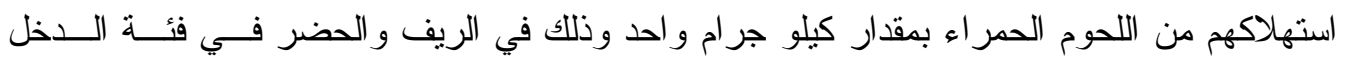

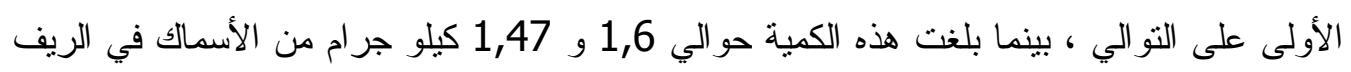

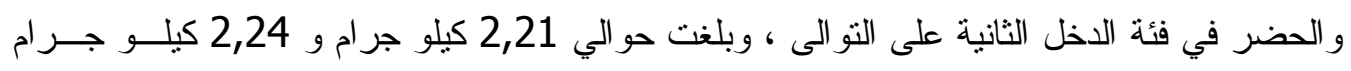

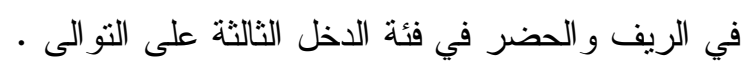
وبمقارنة المعدل الحدي للإحلال بين اللحوم الحمر اءو والأسماك بالنسبة السعرية بين اللحسـوم

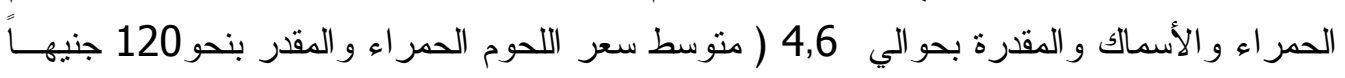

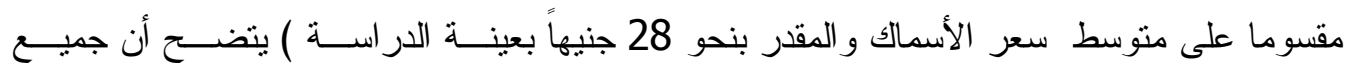

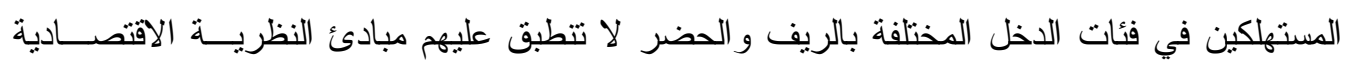

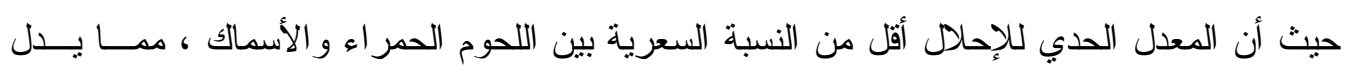

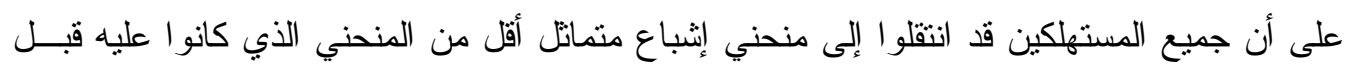

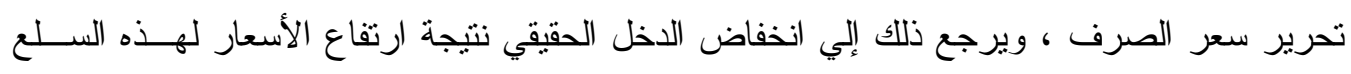

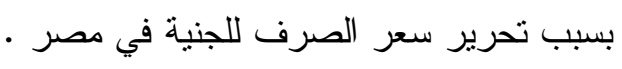

\section{ملخص البحث وأهم النتائج}

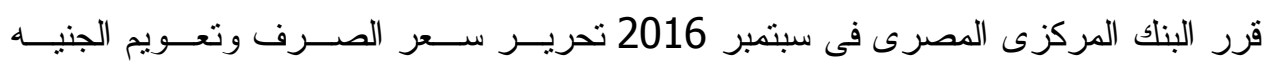

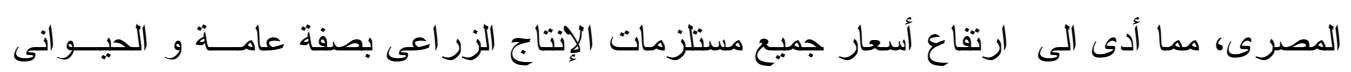

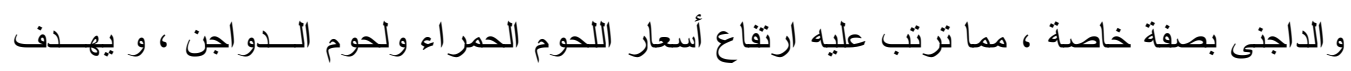

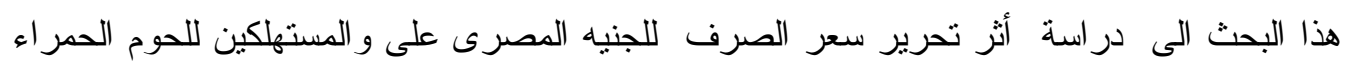

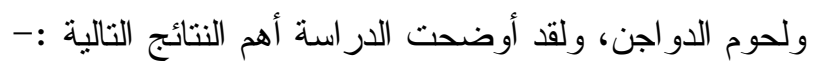

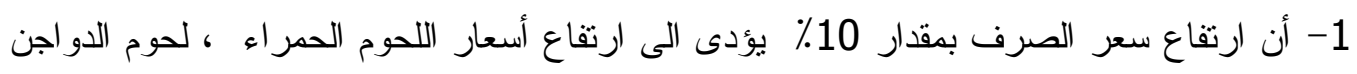

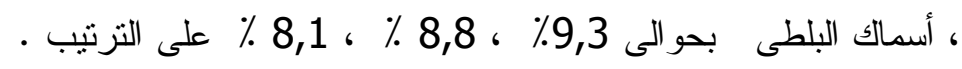

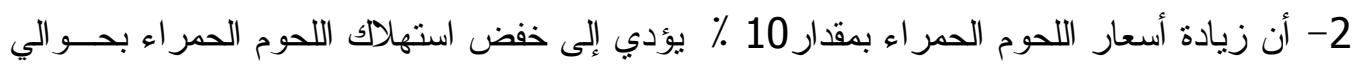

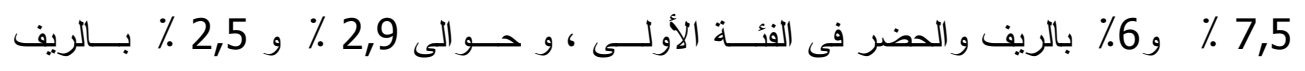

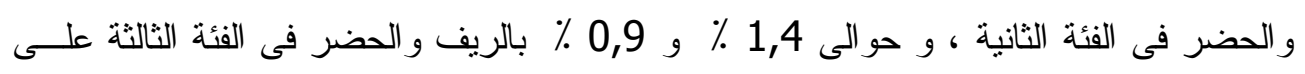

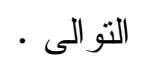

3- أن زيادة دخل الأسرة بمقدار 10٪ بؤدى الى زيادة استهلاك اللحوم الحمر اء بحو الى 1,7 ٪ و و

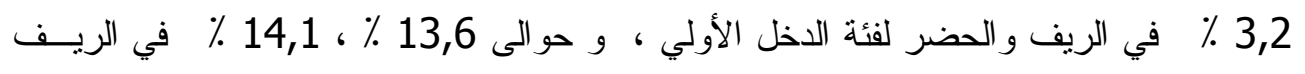
و الحضر لفئة الدخل الثانية ، و حوالى الريفر

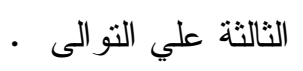
4- أن زيادة أسعار اللحوم الحمر اء بمقدار 10 \% ت تؤدي إلي زيادة استهلالك لحوم الــدو اجن بحـــوالي

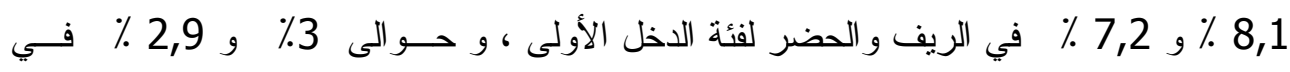

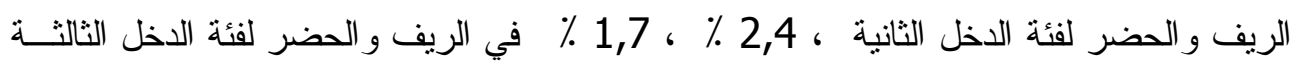

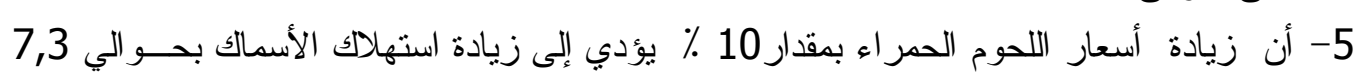

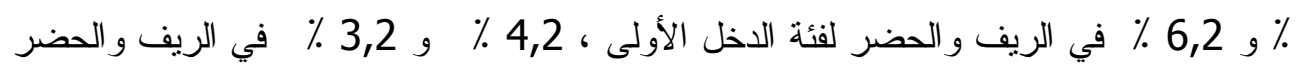

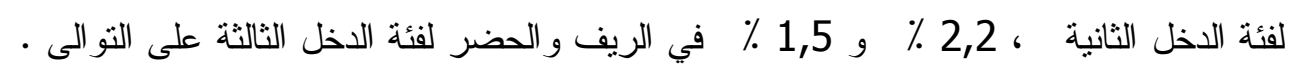




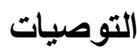

1- عمل مزيد من الدراسات و البحوث التى تمكن و اضعى سياسات الإنتاج و الاستهلاك من ثقـدير

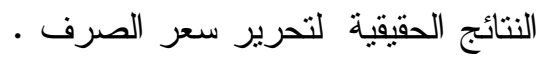

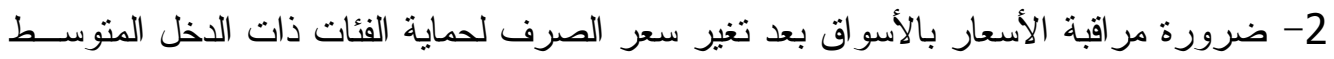

و المنخفض.

3- ضرورة مر اعاة فئات الدخل المنخفض عند وضع سياسات تحرير سعر الصرف.

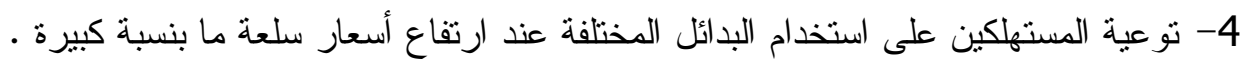

5- زيادة الاهتمام من جانب الدولة بشبكة الأمان الاجتماعى لحماية محدودى الدخل من أثز تحرير

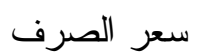

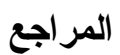

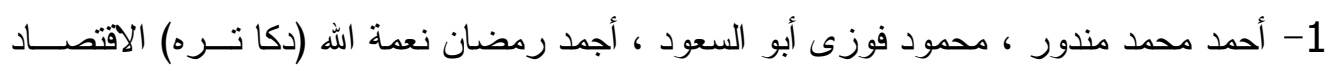

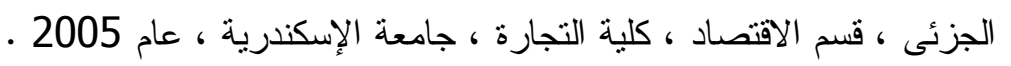

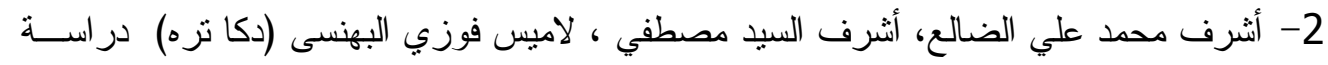

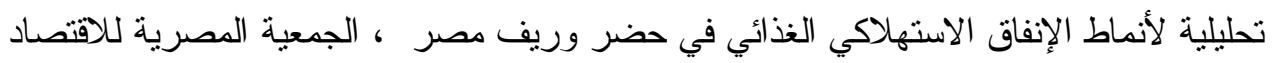

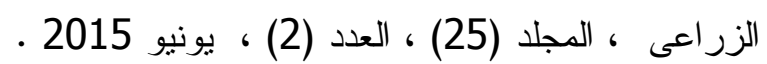

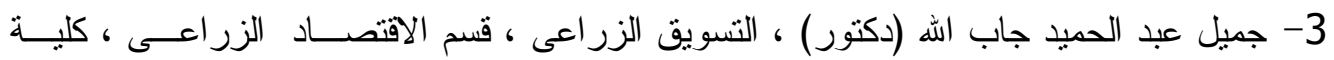

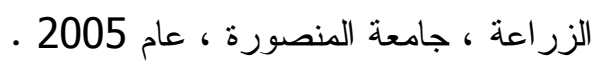

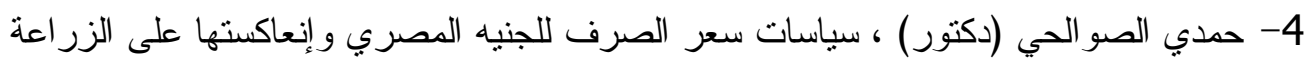

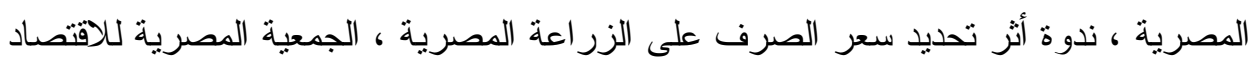

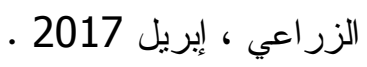

5- صابر سيد أحمد ياسين (دكتور ) ، محاضر ات فئ لـ العينات و المسح الاحصائى، قسم الإقتصاد

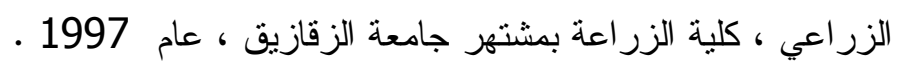

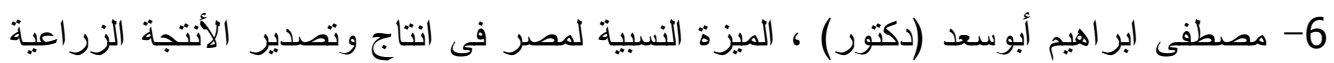

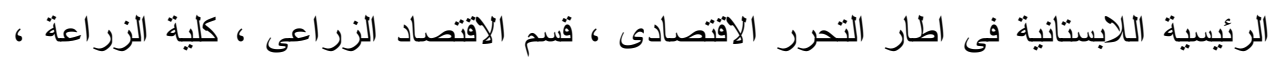
جامعة المنوفية ، 1996 ـ 196

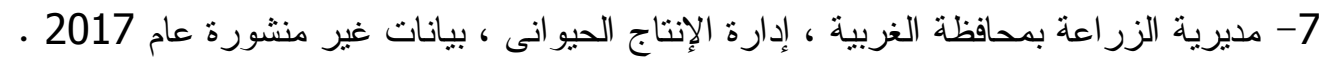

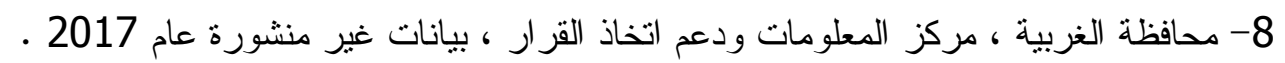

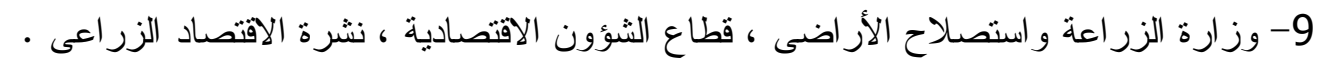

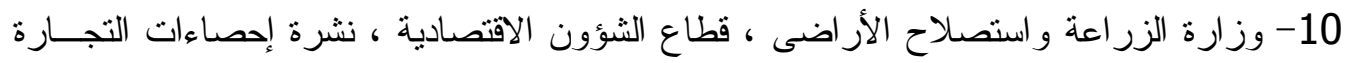
الخارجية للصادر ات و الواردات الزر اعية 2015. 